\section{Influence of Aae Autotransporter Protein on Adhesion and Biofilm Formation by Aggregatibacter actinomycetemcomitans}

Ana Carla Robatto Nunes ${ }^{1,2}$, Priscila Larcher Longo ${ }^{1,3}$, Marcia Pinto Alves Mayer ${ }^{1}$

\begin{abstract}
The periodontopathogen Aggregatibacter actinomycetemcomitans colonizes oral cavity by binding to and invading epithelial cells as well as by participating in biofilms formed on hard surfaces. Aae, an autotransporter protein, is implicated in bacterial adhesion to epithelial cells. Due to the multiple functions of bacterial autotransporter proteins, this study aimed to evaluate the role of aae in A. actinomycetemcomitans ability to adhere to both saliva-coated hydroxyapatite (SHA) and biofilm. An aae null mutant was constructed. Its hydrophobic properties as well as its ability to adhere to epithelial cells, SHA and to form biofilm were evaluated and compared with the parental strain, $A$. actinomycetemcomitans VT1169. The aae null mutant showed reduced hydrophobicity, as well as decreased binding to SHA and biofilm formation compared to the parental strain. These data suggest that aae mediates $A$. actinomycetemcomitans adhesion to epithelial cells and may be involved in biofilm formation and interaction with adsorbed salivary proteins.
\end{abstract}

\author{
'Department of Pediatric Dentistry, \\ EBMSP - Escola Bahiana de Medicina \\ e Saúde Pública, Salvador, BA, Brazil \\ ${ }^{2}$ Department of Microbiology, \\ Institute of Biomedical Sciences, \\ USP - Universidade de São \\ Paulo, São Paulo, SP, Brazil \\ ${ }^{3}$ Medical School, FAM - Faculdade \\ das Américas, São Paulo, SP, Brazil
}

Correspondence: Dra. Marcia P. A. Mayer, Avenida Lineu Prestes, 1374, 05508-900 São Paulo, SP, Brasil. Tel: +55-11-3091-7348. e-mail: mpamayer@icb.usp.br

Key Words: aae, Aggregatibacter actinomycetemcomitans, adhesion, biofilm formation, hydrophobicity.

\section{Introduction}

Adhesion of bacteria to host tissues is the first step in the infectious process (1). The expression of bacterial outer membrane proteins is influenced by both environmental (2) and host factors and has specific interactions with host complementary receptors $(3,4)$. Thus, changes in these bacterial outer membrane proteins may lead to alterations in hydrophobic properties and result in reduced attachment of bacteria to immobilized salivary proteins adsorbed to tooth surfaces or oral mucosa (5).

Adhesive type IV pili mediate Aggregatibacter actinomycetemcomitans ability to colonize tooth surface (1). However, ability to adhere to saliva-coated hydroxyapatite (SHA) is decreased and requires interaction with salivary proteins (6). Non-fimbriated variants exhibiting smooth colony morphology may still adhere to epithelial cells and form biofilms mediated by non-fimbrial components (7-10).

Three autotransporter proteins were recognized as having a role in the interaction of $A$. actinomycetemcomitans with the host: Aae, ApiA or Omp100 and EmaA (1,8-12). Autotransporter proteins are characterized by an aminoterminal leader peptide, a secreted mature protein (or passenger domain) and a C-terminal domain (13). These proteins present huge variations in passenger domain, explaining their wide range of effector functions, such as adhesion, invasion, biofilm formation, autoaggregation and cytotoxicity (14).

Aae and ApiA are both related to adhesion of $A$. actinomycetemcomitans to human buccal epithelial cells (10). An aae null mutant strain has shown decreased adhesion to KB cells, derived from oral carcinoma (8), and total loss of adhesion to buccal epithelial cells (BECs) was found in an aae/apiA double-null mutant (10). Aae specifically binds to BECs (11) and to blood vessel endothelial cells (HUVEC), but the domain involved in binding to $B E C s$ is located in a region of repeats, whereas a different domain is required for adhesion to HUVEC (15).

Aae is identical to the $\mathrm{C}$-terminal region of Haemophilus influenzae IgA1 protease and Hap adhesin, but there is no significant homology of the $\mathrm{N}$-terminal region with other autotransporter proteins listed in the GenBank (1) and this region is related to the $\mathrm{BEC}-$ binding domain (15). In Hap, the C-terminal 311 amino acid of the passenger domain $\left(\mathrm{Hap}_{\mathrm{s}}\right)$ is involved in aggregation, microcolony formation and adhesion to epithelial cells. Furthermore, another domain, located in the C-terminal 511 residue of Hap is involved in binding to laminin, fibronectin and collagen IV (16).

Hence, the present study aimed to test the hypothesis that aae is also involved in A. actinomycetemcomitans ability to adhere to saliva-coated hydroxyapatite (SHA) and in biofilm formation. An aae null mutant was constructed and its ability to adhere to epithelial cells and to SHA as well as to form biofilms was evaluated and compared with the parental strain.

\section{Material and Methods}

\section{Bacterial Strains, Plasmids and KB Cells}

The bacterial strains used in the study are presented 
in Table 1. A. actinomycetemcomitans strains were grown using Trypticase soy broth with $0.6 \%$ yeast extract (TSB$\mathrm{YE}$ ) in humidified $10 \% \mathrm{CO}_{2}$ incubator at $37{ }^{\circ} \mathrm{C}$. Escherichia coli strains were grown in Luria-Bertani (LB) broth at $37{ }^{\circ} \mathrm{C}$. For solid medium, $15 \mathrm{~g} / \mathrm{L}$ of agar were added to liquid medium. Ampicilin, spectinomycin, kanamycin and rifampicin $\left(100 \mu \mathrm{g} \cdot \mathrm{mL}^{-1}\right)$ were added as needed. KB cells were kindly provided by Dr. Paula Fives-Taylor, University of Vermont. Cells were cultured in $75 \mathrm{~cm}^{3}$ flasks with RPMI-1640 medium (Sigma Chemical Co, St. Louis, MO, USA) containing $5 \%$ of fetal bovine serum heat-inactivated (Cultilab, Campinas, SP, Brazil) and supplemented with 50 $\mu \mathrm{g} \cdot \mathrm{mL}^{-1}$ gentamycin at $37{ }^{\circ} \mathrm{C}$ in humidified atmosphere with $5 \% \mathrm{CO}_{2}$.

\section{Aae Knock-Out Mutant}

The aae gene was obtained by amplification using AAE5 (5'CAG AAC CAC AAC CAG TAC CAG CAC AC 3') and AAE3 (5'GCA GAA GTG AGT TAT TCA TCG 3') (24) primers and DNA

Table 1. Bacterial strains and plasmids used in this study

\begin{tabular}{|c|c|c|}
\hline $\begin{array}{l}\text { Bacterial strains } \\
\text { and plasmids }\end{array}$ & Characteristics & $\begin{array}{c}\text { Source } \\
\text { (reference) }\end{array}$ \\
\hline \multicolumn{3}{|l|}{ A. actinomycetemcomitans } \\
\hline SUNY465 & $\begin{array}{l}\text { Clinical isolate, smooth } \\
\text { phenotype, invasive; one } \\
\text { copy of the aae repeat }\end{array}$ & Laboratory* \\
\hline VT1169 & SUNY465 Rif $/ \mathrm{Nal}^{\mathrm{R}}$ & Laboratory* \\
\hline USP29 & aae null mutant strain & This study \\
\hline \multicolumn{3}{|l|}{ Escherichia coli } \\
\hline JM109 & Host for genetic constructions & Laboratory* \\
\hline DH5a(lpir) & Competent cells & Laboratory* \\
\hline SM10(lpir) & Conjugative competent cells & Laboratory* \\
\hline TOPOF 10 & $\begin{array}{l}\text { Electrocompetent cells } \\
\text { used for cloning }\end{array}$ & Invitrogen \\
\hline \multicolumn{3}{|l|}{ Plasmids } \\
\hline pCR2.1-TOPO vector & Cloning PCR products $\left(\mathrm{Kan}^{\mathrm{R}}\right)$ & Invitrogen \\
\hline pGEM-T Easy vector sytem & Cloning PCR products $\left(\mathrm{Amp}^{\mathrm{R}}\right)$ & Promega \\
\hline pVT1460 & Plasmid for allelic exchange & Laboratory* \\
\hline pDL269 & Spectinomycin resistance & Laboratory* \\
\hline paad9 & $\begin{array}{l}\text { Plasmid pCR2.1-TOPO + } \\
\text { spectinomycin resistance gene }\end{array}$ & Laboratory* \\
\hline paae & Plasmid pGEM-T Easy+aae & This study \\
\hline paae/aad9 & $\begin{array}{l}\text { Plasmid pGEM-T Easy+aae } \\
\text { disrupted with aad } 9\end{array}$ & This study \\
\hline pVTaae/aad9 & $\begin{array}{l}\text { Plasmid pVT1460+aae } \\
\text { disrupted with aad9 }\end{array}$ & This study \\
\hline
\end{tabular}

Laboratory*: Dr. Keith Mintz's and Dr. Paula Fives-Taylor's laboratory. from SUNY465 strain as template. PCR was performed in a Gene Amp PCR System 2400 (Perkin Elmer Inc., Norwalk, CT, USA) and consisted of one initial denaturation step $\left(94^{\circ} \mathrm{C}\right.$ for $5 \mathrm{~min}$ ) and 40 cycles of denaturation at $94^{\circ} \mathrm{C}$ for $15 \mathrm{~s}$, annealing at $60{ }^{\circ} \mathrm{C}$ for $30 \mathrm{~s}$ and elongation at $72{ }^{\circ} \mathrm{C}$ for 2 $\min$. The 2,732 bp fragment was cloned into pGEM-T Easy vector (Promega, Madison, WI, USA) and transformed in electrocompetent $E$. coli $\mathrm{DH} 5 \alpha$ (paae). Transformants were selected in LB supplemented with ampicilin. The aae gene was interrupted by insertion of a spectinomycin resistance gene obtained from pdl269. Plasmidial DNA was used as template to amplify the spectinomycin resistance gene, aad9, using forward primer (5' GGTACCAAAGCTITCGT TCG TGA $3^{\prime}$ ) and reverse primer (5' CGCCATAAGCTGGGTATGT $\left.3^{\prime}\right)$. An initial denaturing step at $94{ }^{\circ} \mathrm{C}$ for 5 min was followed by 30 cycles at $94{ }^{\circ} \mathrm{C}$ for $1 \mathrm{~min}, 54{ }^{\circ} \mathrm{C}$ for $30 \mathrm{~s}$ and $72{ }^{\circ} \mathrm{C}$ for $1 \mathrm{~min}$, with a final extension step at $72{ }^{\circ} \mathrm{C}$ for $10 \mathrm{~min}$. The 1,167 bp fragment was cloned into the pCR2.1-TOPO vector (Invitrogen Life Technologies, São Paulo, SP, Brazil) and transformed in E. coli TOPOF10. Transformants were selected in LB supplemented with kanamycin. Plasmid DNA (paad9) was digested with Hindlll. The 1,148 bp Hindlll fragment of paad9 was ligated to paae and transformed in electrocompetent E. coli JM109. Transformants were selected in spectinomycin LB agar. The aae/aad9 fragment was obtained after double digestion with EcoRl and Alw21I (AspHI) (Fermentas Life Sciences, São Paulo, SP, Brazil) ligated into the conjugative plasmid pVT1460 (pVTaae) aad9) and transformed in competent $E$. coli SM10( $\lambda$ pir) cells. Transformant cells were selected in LB with spectinomycin and plasmid identity was confirmed.

An allelic replacement mutagenesis system was used (17) to generate the aae null mutant isogenic to $A$. actinomycetemcomitans VT1169 (SUNY 465, rifampicin and nalidixic acid resistant). A. actinomycetemcomitans VT1169, the recipient strain, and E. coli SM10( $\lambda$ pir)pVTaae/aad9 were grown in broth to reach $\mathrm{OD}_{560 \mathrm{~nm}} \sim 0.3$ and $\sim 0.5$, respectively, and mixed. After conjugation, cells were grown on Trypticase soy agar with $0.6 \%$ yeast extract (TSA-YE) plates containing spectinomycin and rifampicin in $10 \% \mathrm{CO}_{2}$ at $37{ }^{\circ} \mathrm{C}$ for $48 \mathrm{~h}$. Isolated colonies of putative transconjugants were screened by PCR using EXP5 (5' GCA TाT GCG TCA GAG Tा AAT G $\left.3^{\prime}\right)$ and primers (8), located upstream and downstream aae, respectively, exceeding 
the cloned region of aae in pGEM-T Easy vector. Product identities were confirmed by sequencing, performed in MegaBACE100 with DYEnamic ET Dye Terminator Kit (GE Healthcare Bio-Sciences Pittsburgh, PA, USA).

\section{Bacterial Cultures}

A. actinomycetemcomitans VT1169 and USP29 (aae mutant) were grown in TSB-YE added with rifampicin or spectinomycin until mid-exponential phase under microaerophilic $\left(10 \% \mathrm{CO}_{2}\right)$ incubation. The bacterial cultures were adjusted to an ${ }^{0} D_{500 \mathrm{~nm}}$ of 0.20 corresponding to 3 x $10^{8}$ cells.mL ${ }^{-1}$.

\section{Adhesion to KB Cells Assay}

The binding capacity of the aae null mutant was determined by a standard adhesion assay (18). Approximately $2 \times 10^{5} \mathrm{~KB}$ cells/well were seeded in a 24-well tissue culture plate and incubated overnight in $5 \% \mathrm{CO}_{2}$ until confluence. Bacterial suspensions of $A$. actinomycetemcomitans parental strain (VT1169) and aae null mutant (USP29) were added to each well to reach a multiplicity of infection (MOI) of 1:100 (KB cell/ bacteria). After $2 \mathrm{~h}$ of incubation at $37{ }^{\circ} \mathrm{C}$, non-adhesive bacteria were removed by washing with $\mathrm{PBS}$ containing $1.0 \mathrm{mM} \mathrm{CaCl} / 0.5 \mathrm{mM} \mathrm{MgCl}$ and adherent/internalized bacteria were released with $0.1 \%$ Triton $X-100$. Samples were serially diluted and CFU estimated in TSA-YE plates. The experiment was performed in quadruplicate on three independent assays.

\section{Adhesion to Hexadecane}

The adhesion to hexadecane was assessed by a protocol modified as follows (5): bacterial cells were suspended

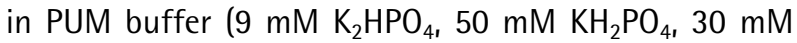
urea, $0.8 \mathrm{mM} \mathrm{MgSO}_{4} .7 \mathrm{H}_{2} \mathrm{O}, \mathrm{pH} 7.1$ ) to an $\mathrm{OD}_{500 \mathrm{~nm}} \sim 0.85$ corresponding to $1 \times 10^{9} \mathrm{CFU} \mathrm{mL}^{1}$, added with hexadecane (Sigma Aldrich, St. Louis, MO, USA). After phase separation, the fraction of adherent cells to hexadecane was estimated according the aqueous phase absorbance.

\section{Biofilm Assay}

Biofilm formation was estimated by a conventional crystal violet staining method (7). Aliquots of bacterial cultures at $10^{6} \mathrm{CFU} \mathrm{mL}-1$ were added to the wells of 96-wells flat-bottom polystyrene microtiter plates (Corning Inc., Corning, NY, USA) and incubated statically under microaerophilic atmosphere at $37{ }^{\circ} \mathrm{C}$ for $14 \mathrm{~h}$. Total cell density was estimated by turbidity measurement at $\mathrm{OD}_{490}$ $\mathrm{nm}$. After washing with phosphate-buffer saline (PBS, pH 7.3), adherent cells were fixed with methanol and stained with $0.1 \%$ crystal violet. The dye was eluted in 95\% ethanol (v/v) and absorbance was measured at $600 \mathrm{~nm}$. Biofilm formation was considered as the ratio between absorbance value of crystal violet eluted from biofilm $\left(0_{600 \mathrm{~nm}}\right)$ and absorbance value obtained from total growth $\left(\mathrm{OD}_{490 \mathrm{~nm}}\right)$. Experiments were made in sextuplicate. Non-inoculated wells were used as controls for sterility.

\section{Adherence to Saliva-Coated Hydroxyapatite}

The adherence to SHA was assessed by a protocol modified as follows (6): whole paraffin-stimulated saliva was obtained from six periodontally and medically healthy adults in wide mouth plastic tubes to achieve a minimum pooled volume of $40 \mathrm{~mL}$. Salivary collection was divided into equal aliquots, frozen, clarified and heated to $60^{\circ} \mathrm{C}$ for 30 min. Spherical hydroxyapatite beads (BDH Chemicals, Poole, U.K.) were added to the saliva and incubated for $2 \mathrm{~h}$ at 37 ${ }^{\circ} \mathrm{C}$ under slow rotation ( $5 \mathrm{rpm}$ ). The hydroxyapatite coated beads were washed, added with bacterial suspensions adjusted to $\sim 3 \times 10^{8} \mathrm{CFU} \mathrm{mL}^{-1}$ in PBS and incubated for $2 \mathrm{~h}$. After washing, cell/bead suspensions were subjected to sonication at low power impulse (Branson Ultrasonic Cleaner, Danbury, CT, USA) and allowed to settle down. Supernatants from non-sonicated (remnant non-adherent cells) and sonicated (adherent plus remnant non-adherent cells) tubes were inoculated on TSA-YE plates for CFU determination. The number of cells attached to SHA was the difference between CFU values determined in supernatant of sonicated and non-sonicated tubes. The experiment was performed in quadruplicate.

\section{Statistical Analysis}

Adhesion to KB cells, biofilm formation and adhesion to SHA of the parental and aqe mutant strains were compared by Student's t-test. Adhesion to $\mathrm{n}$-hexadecane was evaluated by two analyses of variance followed by multiple comparisons Tukey's test. The significance level was set at $p<0.05$.

\section{Results}

\section{Construction of an aae Knock-Out Strain}

The chromosomal aae gene from VT1169 was interrupted by insertion of a spectinomycin cassette ( $a$ ad9) in the HindllI unique site of aae by allelic replacement mutagenesis. Insertion was confirmed by amplification ( . 1) using primers located upstream and downstream the cloned aae gene (EXP5 and AAE3) and sequencing. No differences in growth curves were observed between parental (VT1169) and its isogenic mutant aae- strains (USP29) (data not shown). Both strains reached the mid exponential growth phase after $6 \mathrm{~h}$ in microaerophilic incubation.

\section{Adhesion to KB Cells}

As expected, the aae- mutant exhibited a marked 
reduction in adhesion to KB cells compared with the parental strain $(p<0.01$, Student's t-test). Results were reproducible in three independent assays (Fig. 2A).

\section{Adherence to Hexadecane}

Bacterial cells' hydrophobic properties differed between parental and aqe null mutant strains, with aqe- mutant

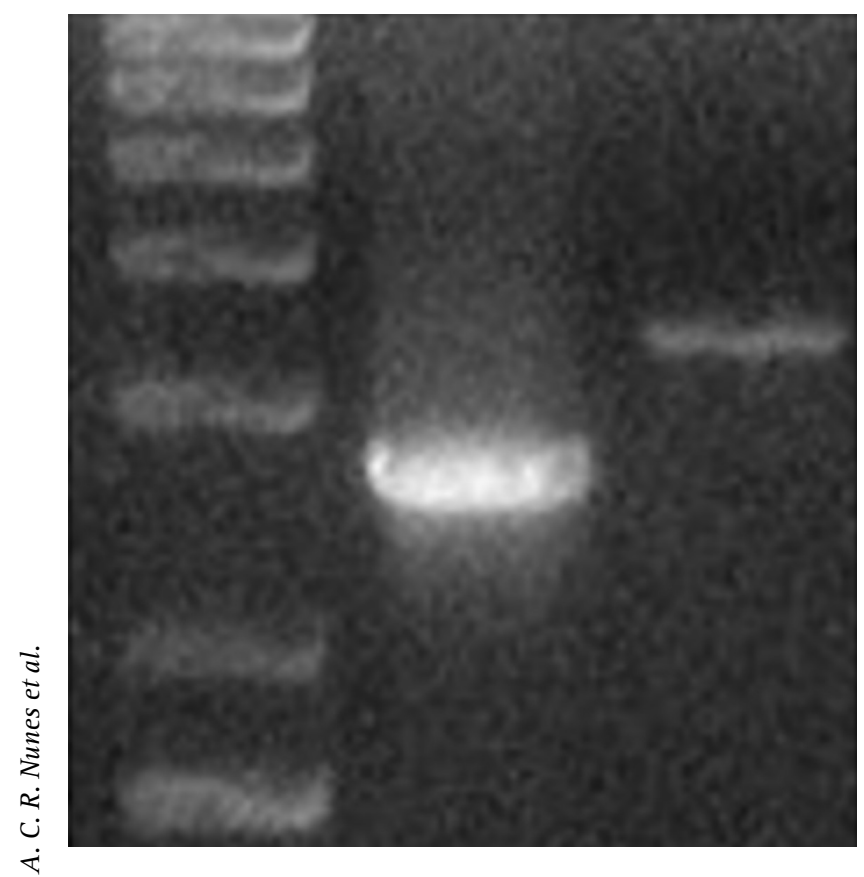

Figure 1. Agarose gel electrophoresis of the amplicons obtained with primers upstream and downstream of aae cloning sites (EXP5-AAE3) using as template DNA VT1169 (parental strain) (lane I) and USP29 $a a e^{-}$mutant strain (lane II). Predicted fragment sizes: lane I, 3,551 bp; lane II 4,698 bp. MW: $1 \mathrm{~Kb}$ plus DNA ladder (Invitrogen Life Technologies). cells being more hydrophilic than those of the parental strain (Fig. 2B) ( $p<0.0001$, Tukey's test).

\section{Biofilm Formation}

The parental strain (VT1169) showed greater ability to form biofilm than the aae null mutant (USP29). After $14 \mathrm{~h}$ of microaerophilic incubation, the aae- mutant showed a $66.5 \%$ reduction in biofilm formation in relation to parental strain (Fig. 2C) ( $p<0.001$, Student's t-test).

\section{Adherence to SHA}

Parental strain adherence to SHA averaged $20.06 \pm 2.99 \times 10^{5} \mathrm{CFU} \mathrm{mL}^{-1}$, whereas only $1.55 \pm 0.29 \times 10^{5}$ $\mathrm{CFU} \mathrm{mL} \mathrm{m}^{-1}$ of the aqe null mutant strain were adherent. Thus, aqe- mutant's ability to adhere to SHA was significantly reduced when compared with the parental type $(p<0.05$, Student's t-test).

\section{Discussion}

In order to investigate the role of aae in oral cavity colonization by $A$. actinomycetemcomitans, an aae null mutant strain was constructed and its phenotype analyzed. This approach, used in several studies analyzing A. actinomycetemcomitans surface proteins, may provide insight of the interaction between multiple bacterial proteins on the cell outer membrane and host receptors $(8,10)$.

Reduced hydrophobicity, decreased ability to bind to saliva-coated hydroxyapatite, and less biofilm formed than in the parental strain was observed. The collected data indicated that aae might also play a role in the interaction with salivary proteins coating the oral surfaces,
A

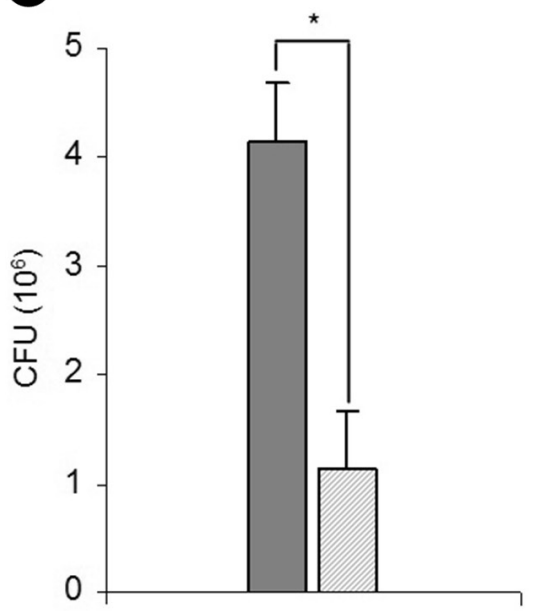

B

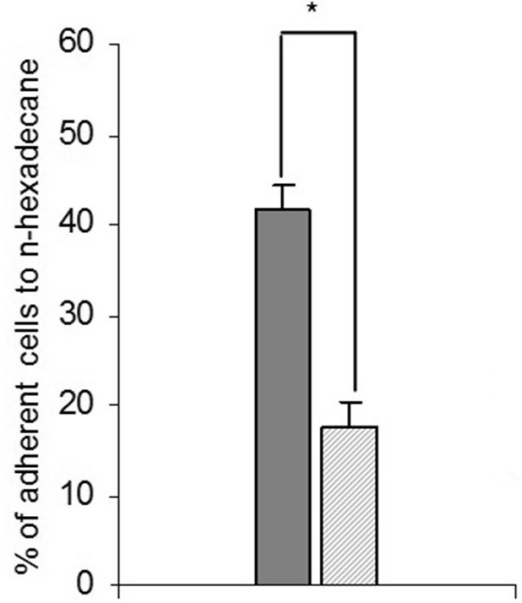

C

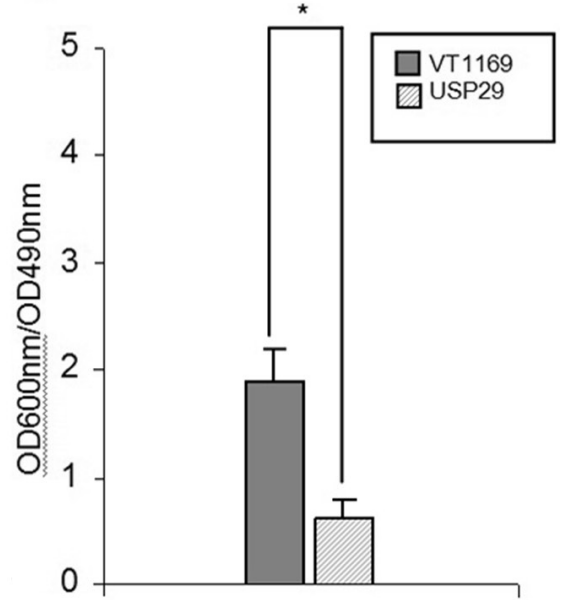

Figure 2. Phenotypic traits of A. actinomycetemcomitans parental (VT1169) and aae null mutant strains (USP29). Asterisk indicates statistically significant differences. A: Binding to KB cells (Student's t-test test, $\mathrm{p}<0.01$ ). B: Percentage of bacteria adherent to n-hexadecane (Tukey's test, $\mathrm{p}<0.0001$ ). C: Biofilm formation (Student's t-test, $\mathrm{p}<0.001$ ). 
increasing the repertoire of attachment mechanisms of $A$. actinomycetemcomitans in the oral cavity.

The ability of $A$. actinomycetemcomitans to bind to epithelial cells has previously been shown (8). In this study, the smooth variant (VT1169) showed higher level of binding to $\mathrm{KB}$ cells than the aqe mutant strain (2-7 bacterial cells/KB cell vs. 1-2 bacterial cells/KB cell, respectively). Hence, the aae- strain exhibited reduced adhesion to KB cells, similar to values obtained in a previous study showing the aae role in adhesion to $\mathrm{KB}$ cells (8). Additionally to Aae, other adhesins like $A$ pi $A$, are involved in $A$. actinomycetemcomitans adhesion to $B E C s(10,11)$. Residual levels of binding to $K B$ cells found in the aae- mutant strain were thus expected.

A serotype b strain was chosen due to its correlation with aggressive disease, reaching high cell counts in the subgingival biofilm, possibly due to more efficient colonization mechanisms (19).

A smooth strain was chosen because the aggregative phenotype observed in rough variants limits calculation of the number of adherent cells to a substrate (6). The aae locus and the loci encoding other surface proteins, such as apiA and emaA, reside outside the tad colonization island and, although smooth-surfaced $A$. actinomycetemcomitans variants have little or no fimbriation, they can adhere to epithelial cells and form biofilm $(3,7)$.

Although both rough and smooth variants are able to produce biofilm in appropriate growth conditions, rough strains produced towers of microcolonies anchored by a small contact area, whereas smooth strains produced biofilm with a reduced height open architecture (7). Since a smooth variant was used, the biofilm studied here was independent from flp-1-mediated fimbriae.

Previous data have demonstrated that aae mutation in a rough strain did not seem to affect the capacity to attach to abiotic surfaces or to form biofilms (1). The present data using a smooth strain showed that biofilm formation was reduced in aqe- null mutant. In smooth variants, its adhesion is mediated by specific non-fimbrial adhesins (9) and possibly other components, such as poly$\mathrm{N}$-acetyl-glucosamine (PGA) (20).

Bacterial binding results from a combination of affinity, electrostatic and hydrophobic interactions. Alterations in bacterial hydrophobic properties are expected when changes occur on cell surface protein composition $(5,21)$. Thus, surface changes caused by aae interruption resulted in more hydrophilic cells. The decreased biofilm formation observed in the aae null mutant strain may indicate a role of aae in this process, either directly or due to changes in cell wall hydrophobic properties, influencing the cell-cell interaction.

The ability to bind to SHA is greater in rough strains of $A$. actinomycetemcomitans than in smooth variants
(6) and addition of saliva to A. actinomycetemcomitans cells reduces adhesion to $K B$ cells (3), indicating that these microorganism surface components interact with salivary proteins. The fimbriae are the main structure involved in biofilm formation in rough variants. However, the addition of polyclonal antiserum against a fimbrial peptide has only partially inhibited the adhesion of smooth variants (22), indicating a role of other surface components. It is currently known that fimbriae, lipopolysaccharide (LPS) and extracellular polymeric substance (EPS) play a role in the biofilm formation of $A$. actinomycetemcomitans and their expression is up regulated by iron limitation and anaerobiosis (23). Our research groups has previously shown that the transcription of aae is not up-regulated in an anaerobic environment (2), thus the present results obtained in microaerophilic atmosphere suggest that aae may be important in the adaptation to host environmental changes, such as increases in oxygen concentrations.

\section{Resumo}

O peridontopatógeno Aggregatibacter actinomycetemcomitans coloniza a cavidade oral aderindo e invadindo as células epiteliais e participando da formação de biofilme em superficies duras. Aae, uma proteina autotransportadora está relacionada com a adesão bacteriana às células epiteliais. Devido às múltiplas funções desempenhadas por proteinas bacterianas autotransportadoras, este estudo teve como objetivo avaliar o papel de aae de $A$. actinomycetemcomitans tanto na capacidade de aderir à hidroxiapatita recoberta por saliva (SHA), quanto a de formar biofilme. Um mutante nulo aae foi construido. Suas propriedades hidrofóbicas, bem como a sia capacidade para aderir às células epiteliais, à SHA e para formar biofilme foram avaliadas e comparadas com a cepa -mãe, A. Actinomycetemcomitans VT1169. 0 mutante nulo aae apresentou redução de hidrofobicidade, assim como diminuição da adesão à SHA e na formação de biofilme, quando comparado à cepa parental. Estes dados sugerem que aae media a adesão de $A$. Actinomycetemcomitans às células epiteliais e pode também estar envolvida na formação de biofilme e na interação com proteinas salivares adsorvidas.

\section{Acknowledgements}

We thank Dr. Paula Fives-Taylor for donating the plasmids, KB cells and bacterial strains. We also thank Rosana Prisco for the statistical analysis. This study was supported by FAPESP grants 03/11172-5 and 03/08598-0.

\section{References}

1. Fine DH, Kaplan JB, Kachlany SC, Schreiner HC. How we got attached to Actinobacillus actinomycetemcomitans: a model for infectious diseases. Periodontol 2000 2006;42:114-157.

2. Longo $\mathrm{PL}$, Nunes $\mathrm{AC}$, Umeda JE, Mayer MP. Gene expression and phenotypic traits of Aggregatibacter actinomycetemcomitans in response to environmental changes. J Periodontal Res. 2013;48:766772.

3. Fives-Taylor PM, Meyer D, Mintz K. Characteristics of Actinobacillus actinomycetemcomitans invasion of and adhesion to cultured epithelial cells. Adv Dent Res 1995;9:55-62.

4. Fives-Taylor PM, Meyer DH, Mintz KP, Brissette C. Virulence factors of Actinobacillus actinomycetemcomitans. Periodontol 2000 1999;20:136-167.

5. Gibbons RJ, Etherden I. Comparative hydrophobicities of oral bacteria and their adherence to salivary pellicles. Infect Immun 1983;41:11901196. 
6. Fine $D H$, Furgang $D$, Schreiner $H C$, Goncharoff $P$, Charlesworth J, Ghazwan G, et al.. Phenotypic variation in Actinobacillus actinomycetemcomitans during laboratory growth: implications for virulence. Microbiol 145;1999:1335-1347.

7. Haase EM, Bonstein T, Palmer Jr RJ, Scannapieco FA. Environmental influences on Actinobacillus actinomycetemcomitans biofilm formation. Arch Oral Biol 2006; 51:299-314.

8. Rose JE, Meyer DH, Fives-Taylor PM. Aae, an autotransporter involved in adhesion of Actinobacillus actinomycetemcomitans to epithelial cells. Infect Immun 2003;71:2384-2393.

9. Ruiz T, Lenox C, Radermacher M, Mintz KP. Novel surface structures are associated with the adhesion of Actinobacillus actinomycetemcomitans to collagen. Infect Immun 2006;74:6163-6170.

10. Yue G, Kaplan JB, Furgang D, Mansfield KG, Fine DH. A second Aggregatibacter actinomycetemcomitans autotransporter adhesin exhibits specificity for buccal epithelial cells in humans and Old World primates. Infect Immun 2007;75:4440-4448.

11. Fine DH, Velliyagounder K, Furgang D, Kaplan JB. The Actinobacillus actinomycetemcomitans autotransporter adhesin Aae exhibits specificity for buccal epithelial cells from humans and Old World primates. Infect Immun 2005;73:1947-1953.

12. Mintz KP. Identification of an extracellular matrix protein adhesin, EmaA, which mediates the adhesion of Actinobacillus actinomycetemcomitans to collagen. Microbiology 2004;150:26772688.

13. Henderson IR, Navarro-Garcia F, Desvaux M, Fernandez RC, Ala'Aldeen D. Type $V$ protein secretion pathway: the autotransporter story. Microbiol Mol Biol Rev 2004;68:692-744.

14. Wells TJ, Tree JJ, Ulett GC, Schembri MA. Autotransporter proteins: novel targets at the bacterial cell surface. FEMS Microbiol Lett. 2007;274:163-172.

15. Fine DH, Kaplan JB, Furgang D, Karched M, Velliyagounder K, Yue G. Mapping the epithelial-cell-binding domain of the Aggregatibacter actinomycetemcomitans autotransporter adhesion Aae. Microbiology 2010;156:3412-3420.
16. Fink DL, Buscher AZ, Green B, Fernsten $P$, St Geme $3^{\text {rd }}$ JW. The Haemophilus influenzae Hap autotransporter mediates microcolony formation and adherence to epithelial cells and extracellular matrix via binding regions in the $\mathrm{C}$-terminal end of the passenger domain. Cell Microbiol 2003;5:175-186.

17. Mintz KP, Fives-Taylor PM. impA, a gene coding for an inner membrane protein, influences colonial morphology of Actinobacillus actinomycetemcomitans. Infect Immun 2000;68:6580-6586.

18. Meyer, DH, Fives-Taylor PM. Characteristics of adherence of Actinobacillus actinomycetemcomitans to epithelial cells. Infect Immun 1994;62:928-935.

19. Yang HW, Asikainen S, Doğan B, Suda R, Lai CH. Relationship of Actinobacillus actinomycetemcomitans serotype $\mathrm{b}$ to aggressive periodontitis: frequency in pure cultured isolates. J Periodontol 2004;4:592-599.

20. Kaplan JB, Velliyagounder K, Ragunath C, Rohde H, Mack D, Knobloch $J K M$, et al.. Genes involved in the synthesis and degradation of matrix polysaccharide in Actinobacillus actinomycetemcomitans and Actinobacillus pleuropneumoniae biofilms. J Bacteriol 2004;186:82138220.

21. Rosenberg M. Microbial adhesion to hydrocarbons: twenty-five years of doing MATH. FEMS Microbiol Lett 2006;262:129-134.

22. Harano $K$, Yamanaka A, Okuda K. An antiserum to a synthetic fimbrial peptide of Actinobacillus actinomycetemcomitans blocked adhesion of the microorganism. FEMS Microbiol Lett. 1995;130:279-285.

23. Amarasinghe JJ, Scannapieco FA, Haase EM. Transcriptional and translational analysis of biofilm determinants of Aggregatibacter actinomycetemcomitans in response to environmental perturbation. Infect Immun 2009;77:2896-2907. 